\title{
CAREER MOTIVATION AND ITS EFFECT ON NURSING
} STAFF BURNOUT

${ }^{1}$ Seham Mohamed Abd EI Rahman, ${ }^{2}$ Ahlam Mahmoud EL Shaer, ${ }^{3}$ Samar Hosny Ahmed

${ }^{1,2}$ Nursing Administration , faculty of Nursing, Mansoura University E-mail: sehammohamed848@gmail.com

\section{Abstract}

Back ground: The need for career motivation is the goal of health care organizations to improve quality of patient care, improve moral state of nurses and decrease the financial loss due to loss of professional nurses. Aim: The study aimed to identify career motivation and burnout among nursing staff in ICUs at Mansoura University Hospitals. Methods: a descriptive correlational design was utilized, included 320 staff nurses and 24 head nurses working in ICUs at Mansoura University Hospitals. Data was collected with using two tools, Career Motivation questionnaire, and Nursing Staff Burnout questionnaire. Results: head nurses had high mean scores for career motivation than staff nurses and staff nurses perceived burnout more than head nurses. There was no statistical significant relation were found between career motivation and burnout. Recommendation: Provide training program about burnout and how to avoid and overcome it. Encourage nursing staff to attain .

Workshops: health conferences to enhance their career motivation.

\begin{abstract}
Introduction
Nurses all over the globe faces many complexities especially in intensive care units (ICUs) that decrease their motivation and make them unable to move forward in their career such as (routine, rules and policies, money, work hours, loss of appreciation., etc.). So the need for career motivation become in increase every day for enhancing the ability to adapt with career circumstances and overcoming all complexities that hind achieving career success, commitment, career efficacy etc. The decrease in career motivation will lead to career, exhaustion or burnout which will be reflected in quality of patient care or increase the shortage of professional nurses who let their job.

Career motivation is the level of energy, commitment, and creativity that a nurses bring to their jobs, in other words is the goal of nurse manger to benefit from psychological forces (like enthusiasm and drives) of nursing staff to
\end{abstract}

improve desirable behaviours to accomplish activities related to work (Riveros\& Tsai, 2011).

Career motivation plays important role in improving career commitment through; mentoring facilities, selfdirectedness, careerinvolvement, career success, and positive attitude. The mentor (most of the time is the manager) may demonstrate the rewards that can be attainedif an individual sticks with a career. And finally mentoring relationship according to the needs and ambitions of individuals (London \&Sessa2006).

Nursing staff who are motivated tend to be more organized, good managed their time, and having more confidence and self-esteem. Careermotivation energize nursing staff to acquire new experiences, knowledge, show their creative side, be empowered and having the ability to choose the best and compete (Aliet al, 2014). 
Nursing staff in ICUs are the highest degree of increasing burnout due to increase job stress, increasing workload, emotional exhaustion and dissatisfaction.Also low recovery rate, little support and physical exhaustion due to increase work hours and night shifts, which have negative effect in patient quality of care, communication with patient relatives and decreasing nursing staff career motivation, which leads to high staff burnout (Chin, 2010).

Burnout is the feeling of exhaustion, a cynical attitude toward the job and people involved in the job through a reduced personnel accomplishment or work efficacy. The incidence of burn out is differing

from registered nurse to practical or licensed nurse, age of experience, and type of relationship between staff and organization, level of career commitment and clinical working area (Meyer\&Martin, 2012).

Nurses with low self-esteem, selfefficacy, and facing environmental adaption problems like inability to complete transition from career choice to enculturation to the practice setting, are the major factors of nursing staff stress, burnout and losing most of their effort in many distractors instead of focusing in career goals (Long, et al,. 2014)

Nurses who suffer from burnout are experienced with physical and emotional exhaustion like headache, and general weakness, sleep disturbance, low self-esteem, and inability to concentrate which will increase work mistakes, complaining, and punctuality problems. Nurses who reported high level of burnout leaving their jobs or have intention to leave it because of increasing of job stress, demotivation, loss of idealism, resignation, disappointment (Aiken, 2002).
Enhancing work group cohesion, creating positive relationship, matching between staff motives and career goals, appreciate or appraise their effort and make them close to decision making, will increase nursing staff commitment, satisfaction, improving career success which is helpful in increasing career motivation, and decreasing nurses burnout and stress (Chin,2010).

\section{Significance of the study}

ICUs have been exposed to in crowded workloads and nurses working in it exposed for high stress and burnout. This consequently for rapidly expanding medical technology, increases job complexity and ethical dilemmas associated with it (Le Blanc et al., 2008). Therefore, currently any health care organization is challenged to improve work of ICUs and create work environment that reduce nurses stress, burnout and increase career motivation. Moreover enhance nurses effectiveness, productivity and quality outcome in care (Le Blanc et al., 2008).

The aim of the study is to;

Assess career motivation and its effect on nursing staff burnoutthrough:

A. Assess nursing staff career motivation in ICUs at Mansoura University Hospitals.

B. Assess the nursing staff burnout in ICUs at Mansoura University Hospitals.

C. Identify the relation between career motivation and nursing staff burnout in ICUs at Mansoura University Hospitals.

\section{Research questions}

RQ1: What's the nursing staff career motivation in ICUs at Mansoura University Hospitals?

RQ2: What's the nursing staff burnout in ICUs at Mansoura

University Hospitals? 
RQ43: Is there a relation between career motivation and nursing staff burnout in ICUs at

Methods Mansoura University

\section{Research design:}

Descriptive design were used:

\section{- Setting:}

This study was conducted in all ICUs (18) at Mansoura University Hospitals namely Main Mansoura University Hospital with bed capacity (1512) bed,Emergency Hospital with bed capacity (195) bed, Paediatric Hospital with bed capacity (334) bedand Medical Specialized Hospital with bed capacity (208) bed, Oncology centre with bed capacity (312) bed, Urology and Nephrology centre with bed capacity (214) bed, and Gastro ecology Surgical centre with bed capacity (200) bed.

\section{- Subject:}

This study included all available nurses and head nurses (total $=344$ ), working in ICUs at Mansoura University Hospitals during data collection as (in the table (a)).

Table (a): Distribution of study subjects at Mansoura University Hospitals.

\begin{tabular}{|c|c|c|c|c|}
\hline Hospital's name & ICUs name & $\begin{array}{c}\text { Number of } \\
\text { beds }\end{array}$ & $\begin{array}{l}\text { Numbers of } \\
\text { head nurses }\end{array}$ & $\begin{array}{c}\text { Number of } \\
\text { nurses }\end{array}$ \\
\hline \multirow{5}{*}{$\begin{array}{l}\text {-Main Mansoura } \\
\text { University Hospital }\end{array}$} & Surgical & 6 & 1 & 12 \\
\hline & Neurology & 6 & 1 & 12 \\
\hline & Anaesthesia & 8 & 1 & 12 \\
\hline & Cardiology & 8 & 1 & 13 \\
\hline & Burns & 6 & 1 & 10 \\
\hline \multirow{4}{*}{ - Emergency Hospital } & Surgical & 11 & 1 & 9 \\
\hline & Medical & 10 & 2 & 9 \\
\hline & Cardiology & 8 & 1 & 9 \\
\hline & New & 9 & 1 & 9 \\
\hline \multirow{3}{*}{ - Paediatric Hospital } & Medical & 12 & 2 & 24 \\
\hline & Surgical & 11 & 1 & 22 \\
\hline & Cardiology\& chest & 11 & 2 & 22 \\
\hline \multirow{3}{*}{$\begin{array}{l}\text {-Medical } \\
\text { Hospital }\end{array}$} & Liver\& G.I.T & 7 & 1 & 15 \\
\hline & Diabetic & 7 & 1 & 71 \\
\hline & Cardiology & 7 & 2 & 71 \\
\hline -Oncology centre & Main ICU & 11 & 2 & 24 \\
\hline $\begin{array}{l}\text {-Urology and Nephrology } \\
\text { centre }\end{array}$ & Urology ICU & 8 & 2 & 41 \\
\hline \multirow{2}{*}{$\begin{array}{c}\begin{array}{c}\text {-Gastro ecology Surgical } \\
\text { centre }\end{array} \\
\text { Total } 7\end{array}$} & Surgical ICU & 5 & 1 & 43 \\
\hline & 18 & 151 & 24 & 320 \\
\hline
\end{tabular}

Tools of data collection: _two tools were used

Tool one: Career Motivation Questionnaire:

This tool was developed by (Toni, et al., 2007) and used to measure nursing staff career motivation, the questionnaire consist of two parts.
Part one: (6 items) demographic data of nursing staff as age, sex, marital status, having children, educational qualification and years of experience.

Part two:(25 items) under 6 dimensions were promotion and growth (5 items), ability for leading and 
overcoming challenges (4 items), ability to benefit from opportunities and achieving goals ( 3 items), being appreciated and respected (5 items), good wages as a motivating factor (3 items), increasing responsibility and work load (5 items).

The responses were set to evaluate via 5 points likert scale ranged from $(1=$ completely false, $2=$ mostly false, $3=$ sometimes true/false, 4= mostly true, and $5=$ completely true) used for response.

Scores were classified into three levels based on cut of point high $>75 \%$, moderate 50-75, and low $<50 \%$

\section{Tool (2): Nursing Staff Burnout Questionnaire: \\ This tool was developed by} (Dawes, 2015) and modified by the researcher used to measure factors that increase nursing staff burnout. This tool include (41 items) under 7 dimensions namely emotional stress and exhaustion (5 items), bad work conditions and loss of interesting ( 11 items), the relationship between nurse manger and nursing staff (5 items), loss of appreciation (5 items), tactful discipline (5 items), loss of involvement with colleagues (5 items), job dissatisfaction (5 items).

The responses were set to evaluate via 5 points to likert scale ranged from $(1=$ never, $\quad$ rarely $=2, \quad$ sometimes $=3$, usually $=4$, and $5=$ constantly) used for responses scores were calculated and classified into three levels based on cut of point for Suffering from severe burnout $(>127)$, moderate level of burnout (68-126), mild level of burnout $(<68)$.

\section{Validity and reliability:}

Data collection tools translated by researcher into Arabic and tasted for its content validity and relevance by five experts in nursing administration from faculties of nursing in Tanta university and Mansoura university who reviewed the tool for clarity, relevance, applicability, comprehensiveness, understanding and accordingly the necessary modification was done according to their opinions. The opinions of the experts for each item were recorded on four point scale: strongly relevant, relevant, not relevant, and strongly not relevant.

Pilot study:

A pilot study for data collection tools were carried out on $10 \%$ (36) of staff nurses and 3 of head nurses that randomly selected, and excluded from the total sample, to test its clarity. Pilot study performed to determine the applicability of the designed tool, and the time consumed for filling the sheet, and to test clarity of the language. It also helped to test the suitability of the study setting. Based on the pilot study, necessary modification includes clarification, rewording. Reliability test of study tools of career motivation and burnout among staff nurses were tested by Cranach's Alpha reliability was computed and found (0.901), (0.887) respectively.

\section{Field work:}

The actual field work at the beginning of May 2016 and completed by the end of august 2016. Data collected through meeting with nursing staff in different shifts every day, and explain the purpose of the study to them. The time needed to complete the sheets is 20 minutes.

\section{Ethical consideration:}

Ethical approval was obtained from research ethics committee of the Faculty of Nursing - Mansoura University. An official permission to conduct the study had obtained from the 
responsible administrators of the hospital. Privacy and Confidentiality of the collected data were assured. Participation in research is voluntary and participation had assure that withdrawing from the study had assured at any stage without responsibility.

\section{Statistical design:}

Data were analysed with SPSS version 21. The normality of data was first tested with one-sample Kolmogorov-Smirnov test. Qualitative data were described using number and percent. Association between categorical variables was tested using Chi-square test and Fisher's Exact Test. Continuous variables were presented as mean \pm $\mathrm{SD}$ (standard deviation) .The two groups were compared with Student $t$ test while ANOVA test was used to compare mean of more than 2 groups. Pearson correlation was used to correlate continuous data. P- Values which were less than 0.05 and 0.01 were considered as statistically significant.

\section{Results:}

$$
\text { Table (1): personal }
$$

characteristics of studied sample:-

The table shows that the majority of staff nurses $(n=320)$ in the age group (20-30) most of them were female, married, having children, having bachelor degree with (1-5) years of experience and most of them working in pediatric hospital.

Regarding head nurses the majority of them $(n=24)$ in the age group (30-40 year) most of them were female, married, having children, having bachelor degree with (11-15) years of experience and most of them working in main Mansoura university hospital, emergency hospital and pediatric hospital.
Table (2): Mean scores of career motivation domains as reported by the studied sample. The table show that staff nurses highest mean score for being appreciated and respect (19.68 \pm 3.35$)$ followed by career promotion and growth (17.89 \pm 4.14$)$ then increasing responsibility and work load was $(17.80 \pm 4.42)$, and the total mean score for career motivation was $(90.54 \pm 14.33)$.

Also, head nurses highest mean score for being appreciated and respected (21.29 \pm 2.62$)$, followed bycareer promotion and growth (19.62 \pm 3.38$)$, then increasing responsibility and work load (18.29 \pm 3.79$)$, and the total mean score for career motivation was $(96.00 \pm 10.13)$.

Statistical significant difference between head nurses and staff nurses regarding career promotion \& growth and being appreciated and respected, which head nurses had the highest mean scores than staff nurses.

Table (3): Mean scores of Nursing Staff Burnout domains as reported by the studied sample.

The table revealed the highly statistical significant differences between head nurses and staff nurses regarded loss of appreciation and job dissatisfaction. Nurses were more loss of appreciation and more job dissatisfaction than head nurses.

Also, staff nurses had highest mean score $(116.39 \pm 22.68)$ as total burnout than head nurses (111.75 \pm 18.16$)$.

Table (4): Correlation between career motivation and burnout subscale among the studied staff nurses $(\mathbf{n}=320)$.

The table show that there were statistical significant negative correlation between emotional stress and exhaustion with good wage as motivating factor and 
positive correlation with increasing responsibilities and workload. Also highly statistical significant negative correlation were found between bad work condition and loss of interesting with promotion and growth, ability for leading and overcoming challenges and ability to benefit from opportunities and achieving goals.

There were also statistical significant positive correlation between good relationship between nurse manger and nursing staff with promotion and growth, good wage as motivating factor, and negative correlation with increasing responsibilities and workload. There were statistical significant negative correlation between loss of appreciation with ability to benefit from opportunities and achieving goals, being appreciated and respected and good wage as motivating factor.

There were statistical significant positive correlation between tactful disciplines with good wage as motivating factor, while negative correlation with increasing responsibility and workload. There were also statistical significant negative correlation between loss of involvement with colleagues with ability for leading and overcoming challenges and highly statistical significant negative correlation with good wage as motivating factor. There were highly statistical significant negative correlation between job dissatisfaction with promotion and growth, ability to benefit from opportunities and achieving goals, and increasing responsibility and workload.

Table 5:Correlation between career motivation and burnout subscale among the studied head nurses $(n=24)$.

The table show that there were highly statistical significant correlation between emotional stress and exhaustion with promotion and growth and positive correlation with increasing responsibilities and workload.

There were statistical significant negative correlation between loss of appreciation with ability to benefit from opportunities and achieving goals, and good wage as motivating factors.

Table (6): Correlation between total career motivation and total nursing staff burnout among the studied sample $(n=344)$.

Show there's no significant relationship between total career motivation and total nursing staff burnout. 
CAREER MOTIVATION AND ITS EFFECT ON etc...

Table 1: Personal characteristics of the studied sample.

\begin{tabular}{|c|c|c|c|c|}
\hline \multirow{2}{*}{ Item } & \multicolumn{2}{|c|}{ Staff nurses $(n=320)$} & \multicolumn{2}{|c|}{ Head nurses $(n=24)$} \\
\hline & No & $\%$ & No & $\%$ \\
\hline \multicolumn{5}{|c|}{ Age (years) } \\
\hline - $\quad<20$ & 12 & 3.8 & 0 & 0.0 \\
\hline - $\quad 20-30$ & 187 & 58.4 & 9 & 37.5 \\
\hline - $\quad 30-40$ & 104 & 32.5 & 14 & 58.3 \\
\hline - $\quad>40$ & 17 & 5.3 & 1 & 4.2 \\
\hline \multicolumn{5}{|c|}{ Gender } \\
\hline - $\quad$ Male & 19 & 5.9 & 1 & 4.2 \\
\hline - Female & 301 & 94.1 & 23 & 95.8 \\
\hline \multicolumn{5}{|c|}{ Marital status } \\
\hline - $\quad$ Single & 48 & 15.0 & 3 & 12.5 \\
\hline - $\quad$ Married & 264 & 82.5 & 16 & 66.7 \\
\hline - $\quad$ Divorced & 5 & 1.6 & 4 & 16.7 \\
\hline - Widow & 3 & 0.9 & 1 & 4.2 \\
\hline \multicolumn{5}{|l|}{ Have children } \\
\hline - Yes & 245 & 76.6 & 22 & 91.7 \\
\hline - $\quad$ No & 75 & 23.4 & 2 & 8.3 \\
\hline \multicolumn{5}{|c|}{ Level of education } \\
\hline - Diploma & 70 & 21.9 & 0 & 0.0 \\
\hline - $\quad$ Nursing institute & 64 & 20.0 & 0 & 0.0 \\
\hline - $\quad$ Bachelor & 178 & 55.6 & 24 & 100.0 \\
\hline - $\quad$ Master degree & 8 & 2.4 & 0 & 0.0 \\
\hline \multicolumn{5}{|c|}{ Years of experience } \\
\hline - $1-5$ & 136 & 42.5 & 0 & 0.0 \\
\hline - $6-10$ & 69 & 21.6 & 8 & 33.3 \\
\hline - $11-15$ & 61 & 19.1 & 14 & 58.3 \\
\hline - $>16$ & 54 & 16.9 & 2 & 8.3 \\
\hline \multicolumn{5}{|c|}{ Place of work } \\
\hline - $\quad$ Mansoura university hospital & 64 & 20.0 & 5 & 20.8 \\
\hline - $\quad$ Emergency hospital & 41 & 12.8 & 5 & 20.8 \\
\hline - $\quad$ Pediatric hospital & 65 & 20.3 & 5 & 20.8 \\
\hline - $\quad$ Internal medicine & 45 & 14.1 & 4 & 16.7 \\
\hline - Oncology center & 22 & 6.9 & 2 & 8.3 \\
\hline - Urology center & 41 & 12.8 & 2 & 8.3 \\
\hline - $\quad$ GIT surgery center & 42 & 13.1 & 1 & 4.2 \\
\hline
\end{tabular}


Seham Mohamed Abd El Rahman et. al.

Table 2: Mean scores of career motivation domains as reported by the studied sample.

\begin{tabular}{|c|c|c|c|c|}
\hline \multirow{2}{*}{$\begin{array}{c}\text { Career motivation } \\
\text { domains }\end{array}$} & $\begin{array}{c}\text { Staff nurses } \\
(n=320)\end{array}$ & $\begin{array}{c}\text { Head nurses } \\
(n=24)\end{array}$ & \multirow[t]{2}{*}{ T-value } & \multirow[t]{2}{*}{$\mathbf{P}^{*}$} \\
\hline & Mean \pm SD & Mean \pm SD & & \\
\hline $\begin{array}{l}\text { - Career promotion and } \\
\text { growth }\end{array}$ & $17.89 \pm 4.14$ & $19.62 \pm 3.38$ & 1.99 & $0.02 *$ \\
\hline $\begin{array}{l}\text { Ability for leading } \\
\text { and overcoming } \\
\text { challenges }\end{array}$ & $14.50 \pm 3.63$ & $15.91 \pm 2.84$ & 1.86 & 0.06 \\
\hline \begin{tabular}{|l|}
$\begin{array}{l}\text { Ability to benefit } \\
\text { from opportunities } \\
\text { and achieving goals }\end{array}$ \\
\end{tabular} & $13.09 \pm 2.39$ & $13.62 \pm 1.27$ & 1.07 & 0.28 \\
\hline $\begin{array}{l}\text { - } \begin{array}{l}\text { Being appreciated and } \\
\text { respected }\end{array} \\
\end{array}$ & $19.68 \pm 3.35$ & $21.29 \pm 2.62$ & 2.29 & $0.02 *$ \\
\hline $\begin{array}{l}\text { Good wages as a } \\
\text { motivation factor }\end{array}$ & $7.56 \pm 3.71$ & $7.25 \pm 2.99$ & 0.40 & 0.68 \\
\hline \begin{tabular}{|l|} 
Increasing \\
responsibility and \\
work load
\end{tabular} & $17.80 \pm 4.42$ & $18.29 \pm 3.79$ & 0.53 & 0.59 \\
\hline Total career motivation & $90.54 \pm 14.33$ & $96.00( \pm 10.13$ & 1.83 & 0.06 \\
\hline
\end{tabular}

* Statistically Significant $(\mathbf{P} \leq \mathbf{0 . 0 5})$

** Highly statistically Significant $(\mathbf{P} \leq \mathbf{0 . 0 1})$

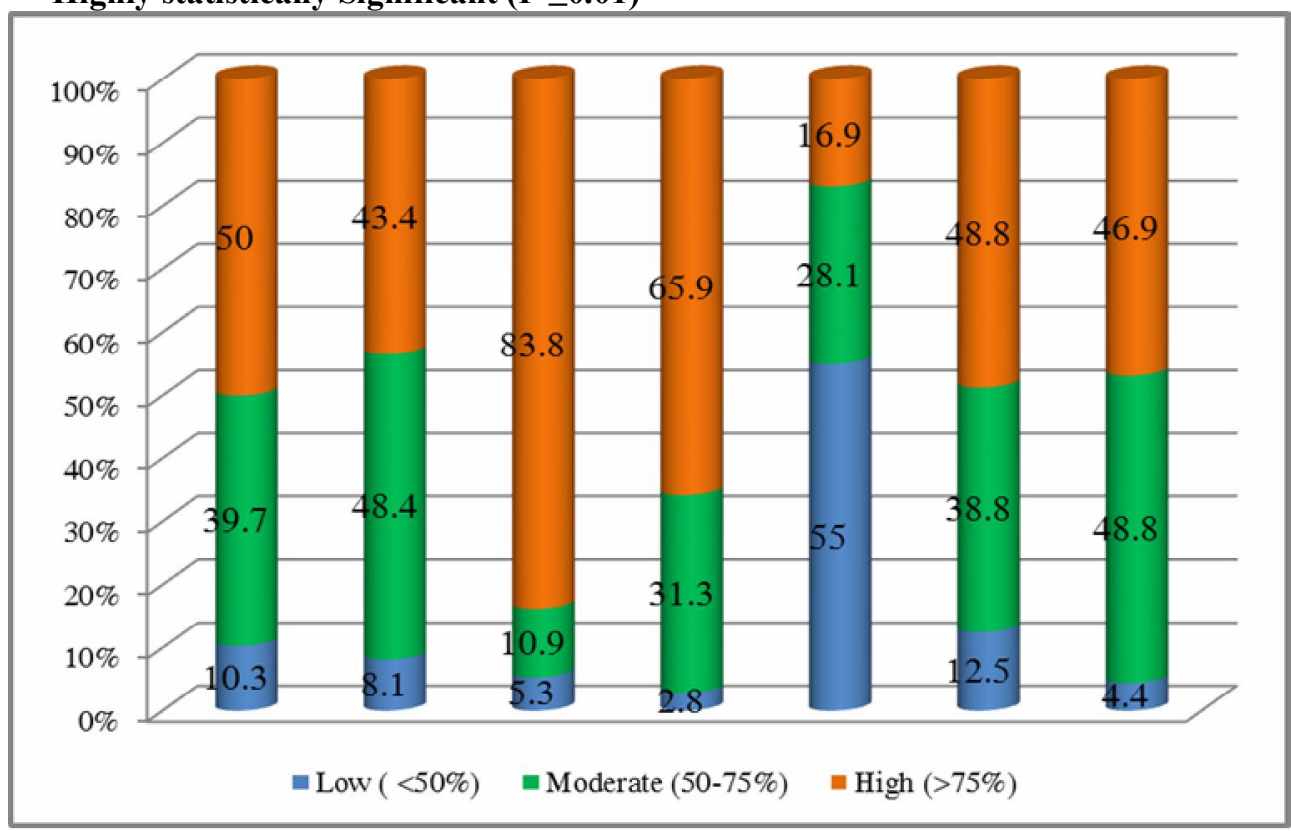

Figure 1:Levels of career Motivation as reported by the studied staff nurses( $n=320)$ 


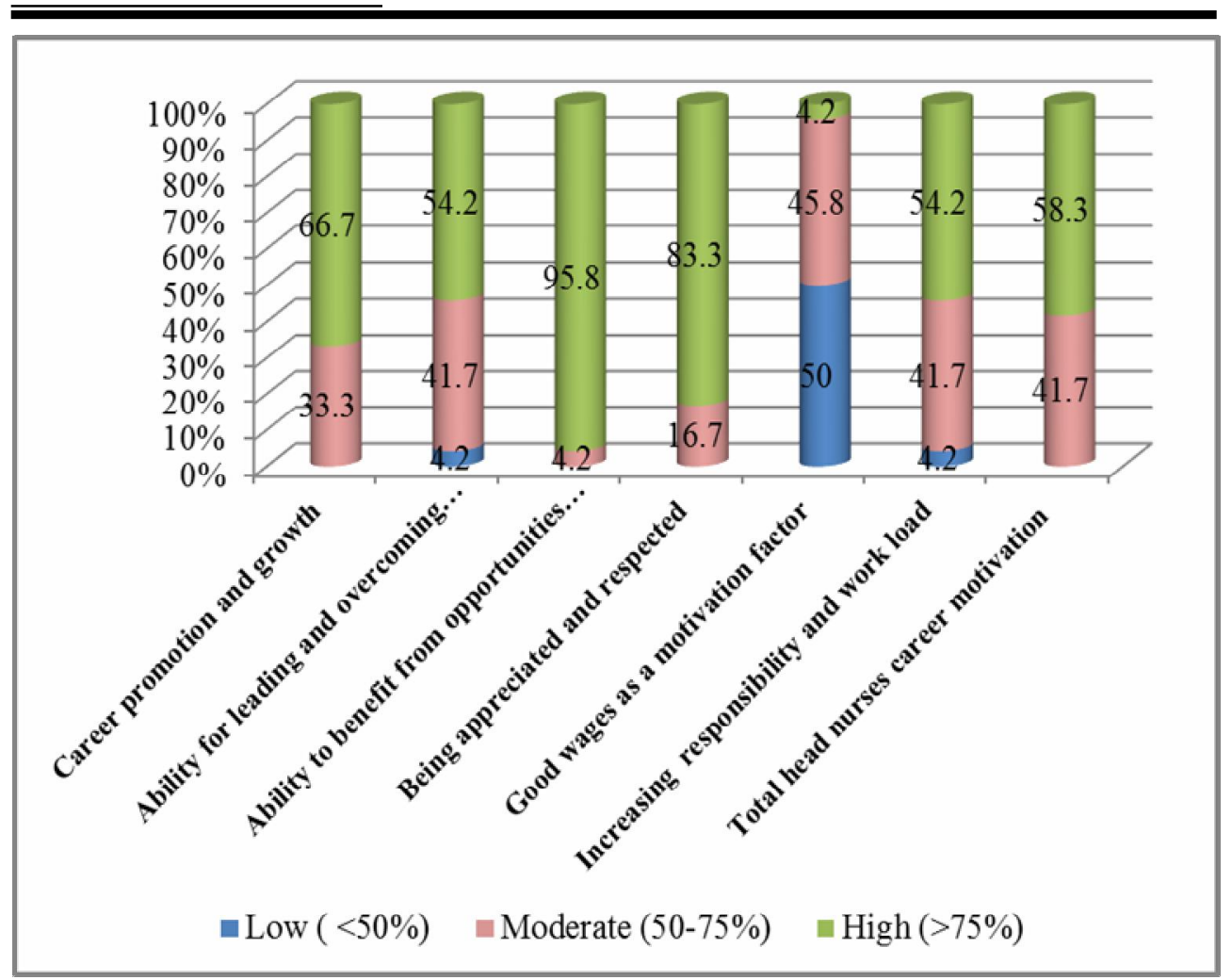

Figure 2: Levels of career Motivation as reported by the studied head nurses $(n=24)$.

Table 3: Mean scores of Nursing Staff Burnout domains as studied sample.

\begin{tabular}{|c|c|c|c|c|}
\hline \multirow[t]{2}{*}{ Nursing Staff burnout domains } & $\begin{array}{c}\text { Staff nurses } \\
(n=320)\end{array}$ & $\begin{array}{c}\text { Head nurses } \\
(\mathrm{n}=\mathbf{2 4})\end{array}$ & \multirow[t]{2}{*}{ T-value } & \multirow[t]{2}{*}{$\mathbf{P} *$} \\
\hline & Mean \pm SD & $\operatorname{Mean} \pm$ SD & & \\
\hline 1. Emotional stress and exhaustion & $13.59 \pm 3.86$ & $13.00 \pm 4.37$ & 0.71 & 0.47 \\
\hline $\begin{array}{l}\text { 2. Bad work conditions and loss of } \\
\text { interesting }\end{array}$ & $\mid 39.95 \pm 7.19$ & $40.62 \pm 5.13$ & 0.45 & 0.65 \\
\hline $\begin{array}{l}\text { 3. The relationship between nurse } \\
\text { manger and nursing staff }\end{array}$ & $13.90 \pm 3.90$ & $14.25 \pm 4.36$ & 0.40 & 0.68 \\
\hline 4. Loss of appreciation & $11.48 \pm 3.28$ & $9.16 \pm 3.88$ & 3.28 & $0.001 * *$ \\
\hline 5. Tactful discipline & $11.83 \pm 4.37$ & $11.00 \pm 3.82$ & 0.90 & 0.36 \\
\hline \begin{tabular}{|lll} 
6. Loss of involvement with \\
colleagues
\end{tabular} & $13.58 \pm 4.90$ & $14.08 \pm 3.22$ & 0.49 & 0.62 \\
\hline 7. Job dissatisfaction & $12.41 \pm 3.53$ & $9.62 \pm 3.66$ & 3.23 & $0.001 * *$ \\
\hline Total Nursing Staff Burnout & $116.39 \pm 22.68$ & $111.75 \pm 18.16$ & 0.97 & 0.32 \\
\hline
\end{tabular}

* Statistically Significant $(\mathbf{P} \leq \mathbf{0 . 0 5})$

$* *$ Highly statistically Significant $(\mathbf{P} \leq \mathbf{0 . 0 1})$ 
Seham Mohamed Abd El Rahman et. al.

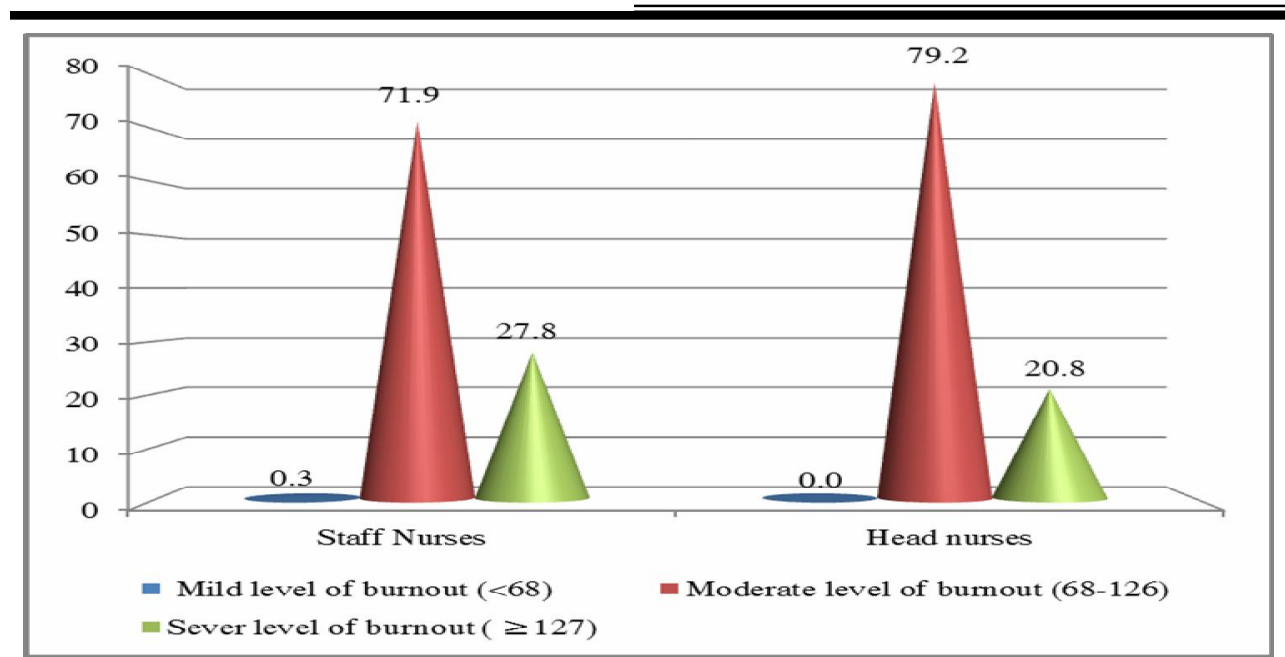

Figure 1: Levels of Nursing Staff Burnout as reported by the studied sample.

Table 4: Correlation between career motivation and burnout subscale among the studied staff nurses $(n=320)$.

\begin{tabular}{|c|c|c|c|c|c|c|c|c|c|c|c|c|}
\hline \multirow{3}{*}{$\begin{array}{l}\text { Nursing staff } \\
\text { burnout } \\
\text { subscale }\end{array}$} & \multicolumn{12}{|c|}{ Career motivation subscale } \\
\hline & \multicolumn{2}{|c|}{$\begin{array}{l}\text { Promotion } \\
\text { and growth }\end{array}$} & \multicolumn{2}{|c|}{$\begin{array}{l}\text { Ability for } \\
\text { leading and } \\
\text { overcoming } \\
\text { challenges }\end{array}$} & \multicolumn{2}{|c|}{\begin{tabular}{|c|} 
Ability to \\
benefit from \\
opportunities \\
and achieving \\
goals \\
\end{tabular}} & \multicolumn{2}{|c|}{$\begin{array}{c}\text { Being } \\
\text { appreciated } \\
\text { and } \\
\text { respected }\end{array}$} & \multicolumn{2}{|c|}{$\begin{array}{c}\text { Good wages as } \\
\text { a motivation } \\
\text { factor }\end{array}$} & \multicolumn{2}{|c|}{$\begin{array}{c}\text { Increasing } \\
\text { responsibility } \\
\text { and work load }\end{array}$} \\
\hline & $\mathbf{R}$ & $\mathbf{P}$ & $\mathbf{R}$ & $\mathbf{P}$ & $\mathbf{R}$ & $\mathbf{P}$ & $\mathbf{R}$ & $\mathbf{P}$ & $\mathbf{r}$ & $\mathbf{P}$ & $\mathbf{R}$ & $\mathbf{P}$ \\
\hline $\begin{array}{l}\text { 1. } \begin{array}{l}\text { Emotional } \\
\text { stress and } \\
\text { exhaustion }\end{array} \\
\end{array}$ & 0.04 & 0.44 & 0.01 & 0.79 & 0.01 & 0.81 & 0.02 & 0.61 & 0.12 & $-0.02 *$ & 0.17 & $0.002 * *$ \\
\hline $\begin{array}{l}\text { 2. Bad work } \\
\text { conditions } \\
\text { and loss of } \\
\text { interesting } \\
\end{array}$ & 0.15 & $-0.005 * *$ & 0.15 & $-0.005 *$ & 0.13 & $-0.01 * *$ & 0.09 & 0.08 & 0.02 & 0.68 & 0.01 & 0.84 \\
\hline $\begin{array}{l}\text { 3. The } \\
\text { relationship } \\
\text { between nurse } \\
\text { manger and } \\
\text { nursing staff } \\
\end{array}$ & 0.10 & $0.05 *$ & 0.03 & 0.55 & 0.01 & 0.78 & 0.07 & 0.16 & 0.15 & $0.007 * *$ & 0.14 & $-0.008 * *$ \\
\hline $\begin{array}{l}\text { 4. Loss of } \\
\text { appreciation }\end{array}$ & 0.02 & 0.64 & 0.00 & 0.95 & 0.16 & $-0.003 * *$ & 0.12 & $-0.02 \%$ & 0.24 & $-0.000 * *$ & 0.08 & 0.14 \\
\hline $\begin{array}{ll}\text { 5. } & \text { Tactful } \\
\text { discipline }\end{array}$ & 0.01 & 0.79 & 0.04 & 0.47 & 0.03 & 0.58 & 0.08 & 0.13 & 0.22 & $0.000 * *$ & 0.11 & $-0.04 *$ \\
\hline \begin{tabular}{|l} 
6. Loss of \\
involvement \\
with \\
colleagues \\
\end{tabular} & 0.06 & 0.22 & 0.11 & $-0.04 *$ & 0.09 & 0.10 & 0.01 & 0.82 & 0.18 & $-0.001 * *$ & 0.03 & 0.53 \\
\hline 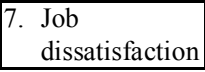 & 0.14 & $-0.008 * *$ & 0.10 & 0.07 & 0.14 & $-0.008 * *$ & 0.18 & $-0.01 * *$ & 0.05 & 0.34 & 0.29 & $0.000 * *$ \\
\hline
\end{tabular}

* Statistically significant at $\mathbf{p} \leq \mathbf{0 . 0 5}$

$* *$ Highly statistically significant at $\mathbf{p} \leq 0.01$ 
Table 5: Correlation between career motivation and burnout subscale among the studied head nurses $(n=24)$.

\begin{tabular}{|c|c|c|c|c|c|c|c|c|c|c|c|c|}
\hline \multirow{3}{*}{$\begin{array}{c}\text { Nursing staff } \\
\text { burnout } \\
\text { subscale }\end{array}$} & \multicolumn{12}{|c|}{ Career motivation subscale } \\
\hline & \multicolumn{2}{|c|}{$\begin{array}{l}\text { Promotion } \\
\text { and growth }\end{array}$} & \multicolumn{2}{|c|}{$\begin{array}{c}\text { Ability for } \\
\text { leading and } \\
\text { overcoming } \\
\text { challenges }\end{array}$} & \multicolumn{2}{|c|}{$\begin{array}{c}\text { Ability to } \\
\text { benefit from } \\
\text { opportunities } \\
\text { and } \\
\text { achieving } \\
\text { goals }\end{array}$} & \multicolumn{2}{|c|}{$\begin{array}{c}\text { Being } \\
\text { appreciated } \\
\text { and } \\
\text { respected }\end{array}$} & \multicolumn{2}{|c|}{$\begin{array}{c}\text { Good } \\
\text { wages as a } \\
\text { motivation } \\
\text { factor }\end{array}$} & \multicolumn{2}{|c|}{$\begin{array}{c}\text { Increasing } \\
\text { responsibility } \\
\text { and work } \\
\text { load }\end{array}$} \\
\hline & $\mathbf{R}$ & $\mathbf{P}$ & $\mathbf{R}$ & $\mathbf{P}$ & $\mathbf{R}$ & $\mathbf{P}$ & $\mathbf{R}$ & $\mathbf{P}$ & $\mathbf{R}$ & $\mathbf{P}$ & $\mathbf{r}$ & $\mathbf{P}$ \\
\hline \begin{tabular}{|l|l|}
1. & $\begin{array}{l}\text { Emotional } \\
\text { stress and } \\
\text { exhaustion }\end{array}$ \\
\end{tabular} & 0.60 & $-\overline{0.002} *$ & 0.32 & 0.12 & 0.31 & 0.12 & 0.07 & 0.72 & 0.38 & 0.06 & 0.47 & $0.01 * *$ \\
\hline $\begin{array}{|ll|}2 . & \text { Bad work } \\
\text { conditions } \\
\text { and loss of } \\
\text { interesting } \\
\end{array}$ & 0.28 & 0.17 & 0.004 & 0.98 & 0.09 & 0.65 & 0.12 & 0.55 & 0.05 & 0.81 & 0.09 & 0.65 \\
\hline 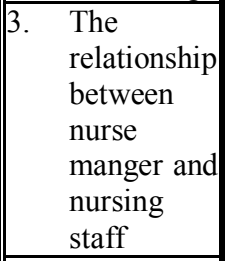 & 0.20 & 0.33 & 0.27 & 0.19 & 0.07 & 0.72 & 0.12 & 0.56 & 0.37 & 0.06 & 0.11 & 0.60 \\
\hline $\begin{array}{|ll|}4 . & \text { Loss of } \\
& \text { appreciatio } \\
& \mathrm{n} \\
\end{array}$ & 0.18 & 0.38 & 0.08 & 0.67 & 0.41 & $-0.04 *$ & 0.09 & 0.66 & 0.42 & $\overline{-}-$ & 0.13 & 0.52 \\
\hline $\begin{array}{|ll|}5 . & \begin{array}{l}\text { Tactful } \\
\text { discipline }\end{array} \\
\end{array}$ & 0.21 & 0.32 & 0.06 & 0.78 & 0.32 & 0.11 & 0.06 & 0.77 & 0.10 & 0.63 & 0.12 & 0.56 \\
\hline $\begin{array}{|llr|}6 . & \text { Loss of } \\
& \text { involvemen } \\
& \mathrm{t} \quad \text { with } \\
& \text { colleagues } \\
\end{array}$ & 0.18 & 0.39 & 0.01 & 0.95 & 0.04 & 0.83 & 0.09 & 0.65 & 0.04 & 0.84 & 0.14 & 0.50 \\
\hline $\begin{array}{|ll|}7 . & \text { Job } \\
& \text { dissatisfacti } \\
\text { on }\end{array}$ & 0.01 & 0.94 & 0.11 & 0.59 & 0.03 & 0.88 & 0.26 & 0.20 & 0.21 & 0.31 & 0.02 & 0.89 \\
\hline
\end{tabular}

* Statistically significant at $\mathbf{p} \leq \mathbf{0 . 0 5}$

$* *$ Highly statistically significant at $\mathbf{p} \leq \mathbf{0 . 0 1}$

Table 6: Correlation between total career motivation and total nursing staff burnout among the studied sample $(\mathrm{n}=344)$.

\begin{tabular}{||c||c|c|}
\hline \multirow{2}{*}{} & \multicolumn{2}{|c||}{ Total nursing staff burnout score } \\
\cline { 2 - 3 } & $\mathbf{r}$ & $\mathbf{P}$ \\
\hline Total Career motivation score & 0.01 & 0.83 \\
\hline
\end{tabular}




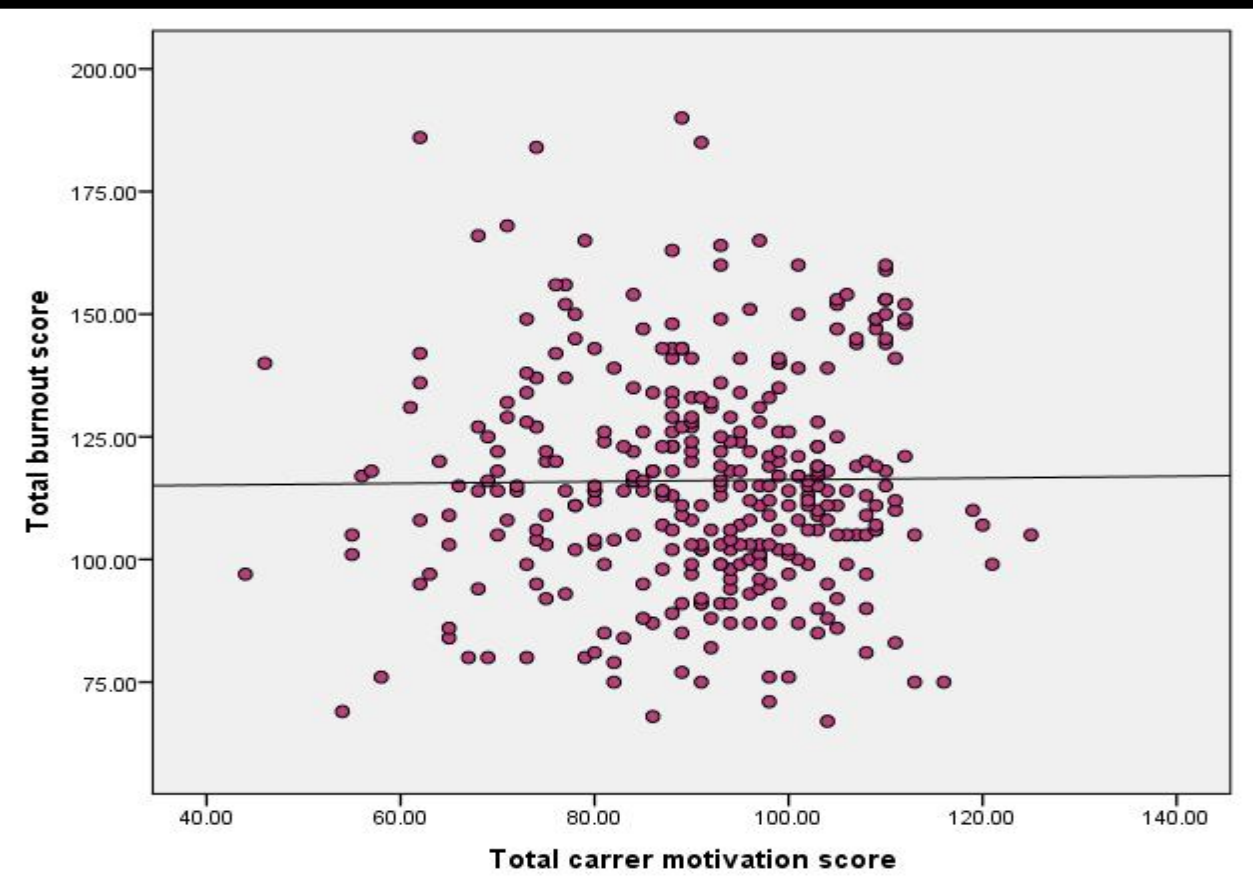

Figure 2: Correlation between total career motivation and total nursing staff burnout among the studied $(n=344)$.

\section{Discussion:}

Career motivation is the fuel or the magic button that open and workout all performance problems of nursing staff and help them to exert their effort without exposure to stressor factors that will lead to burnout. That will destroy they wellness to improve quality of patient care, and will create a massive disturbance of nurses leading to let their job or try to escape from their responsibilities.

Concerning career motivation the present study revealed that head nurses had high mean scores for career motivation than staff nurses because head nurses perceived them that they have high appreciation and respected, high career promotion and growth, increasing responsibility and workload, in addition increase their ability for leading and overcoming challenges than staff nurses. Moreover, head nurses had ability to deal with criticism in diplomatic way, high volunteers for leadership role, had more ambition to prove themselves, they had abilities to learn new things in different stages in career, and had pride selfesteem.

These result is agreed with Banks and Bailey (2010)through her study of career motivation reported that the increase of career motivation among head nurses leads to high career identity, more career commitment, improve their leadership skills which reflect in positive way in staff nurses which motivate them to improve their performance to have more career progress and to increase the productivity.

In the same line another study had done by Handbook (2015) found that the decrease of treating staff nurses with respect will lead to aggressive relation with patient, feeling un stable in her career, career dissatisfaction, increase 
intention to take vacations or to resigns and they are the main power of health care system.

in contrast with Meyer and Maltin (2010)who found that career motivation hadn't no difference between head nurses and staff nurses regarding career motivation it may be due to individual differences likethe desire to have new responsibility, or the desire to control the quality of care, having the new experience and skills to maintain several behaviour, highly competitive spirit, highly analytical skills and problem solving experience.

Concerning burnout this result shows that staff nurses perceived burnout more than head nurses. This result due to staff nurses had job dissatisfaction than head nurses and loss of appreciation due to they were well trained, had high skills which make them over qualified than tasks assigned to them, they work hard and they didn't have the credit for their work, they feel isolated, and they don't had the career progress that as they wanted. In the same line with Smith and Worsfold (2015) who found the stress and over pressure due to overwhelming work and the absence of appreciation to the work exerted by staff nurses which make her to struggle to prove herself which leads to lose of her energy.

This also agree withTzeng, (2002)in his empirical investigation in Taiwanreported found the stress and over pressure due to overwhelming work and the absence of appreciation to the work exerted by staff nurses which make her to struggle to prove herself which leads to lose of her energy.

This study also revealed that nearly all nursing staff perceived themselves had moderate and high level of burnout. This may be due to they experienced more emotional stress and exhaustion, bad work conditions, loss of interesting, bad relationship between nurse manger and nursing staff and loss involvement with colleagues.

This agreed with Nelson and Cavanagh (2018)in his study of measuring nurse satisfaction in Jamaica reported that the continuous pressure which nursing staff expose to it, will increase their need to have more flexible work condition, like choosing work group to have more cooperation with increasing workloads, also need to share in decision making to maintain their problems will have the practical solutions which will decrease their stress.

As well asBagley et al. (2018)who found that the stress that nurses had inside and outside their work and the continuous need to balance between increase workload and their special life make them required to special support from their managers to increase their self-esteem and to appreciate their effort will decrease their exhaustion and give them the energy to continue.

This study revealed that although there's no statistical significant relation were found between career motivation and burnout, correlation were found among nurses between emotional stress and exhaustion with good wage as motivating factor and positive correlation with increasing responsibility and workload.

This result agree with Antoniou et al. (2013) who found the increase of workload and working in the difficult environment like ICUs which have special requirements with increase of death rate and complete care to dependant patient, long $12 \mathrm{hrs}$ shifts which mean more stress and loss of energy and using money and bounces to 
attract nurses to overcome this exhaustion, and enhance them to achieve her life demands which had effective role on decreasing stress.

As well as Maslach and Leiter (2016) also reported that the main factors that increase burnout emotional stress and exhaustion which occurs due to many factors one of them the decrease in wages that affect his life needs and increase of work load and responsibility which increase the nurse stress.

This study found that a statistical correlation were found among staff nurses between bad work conditions and loss of interesting with promotion and growth, ability for leading and overcoming challenges and ability to benefit from opportunities and achieving goals. this agree with Taylor and Hooley (2014). Who reported that the decreases of supplies and equipment, lack of staff nurses, unrecognized roles, bad work routines and other hazards increase the difficulties to lead, direct and control of nurses behaviour and decrease the chances to achieving goals which increase work stress.

As wellSchaufeli et al. (2009) who found that to achieve work satisfaction and success, the difficult work circumstances should be controlled which will facilitate leading and increase opportunities for success and increase work growing for staff nurses and will enhance their positive feelings.

Also the study shows a correlation were found among staff nurses between the relationship between nurse manager and nursing staff with promotion and growth, good wages as motivating factor and increasing responsibilities and workload.

This agree with Kong et al. (2011)who reported that manager is the first man in the organization whose opinion affects in decision making putting policies and roles and had good relationship between staff and manger like empowering them and sharing in problem solving, will enhance nurses to grow rapidly in their positions which will reflect positively in their wages and good distribution of work among nurses and defining every one role will decrease the workload and enhance career satisfaction.

In the same lines a study done by Negarandeh et al. (2006) who found that the relationship between nurse manger and nursing staff affects many sides like promotion and growth of staff due to the need of work, enhancing appropriate behaviour by controlling financial rewards and distributing workloads and responsibilities on nurses like dividing them to work in groups and distributing roles everyone knows her role to maintain the equity between staff and the care of the patient is complete and qualified.

This study revealed that negative correlation were found among staff nurses between loss of appreciation with ability to benefit from opportunities and achieving goals, being appreciated and respected and good wages as motivating factors.

This agree withCarr et al. (2003) who report that enhancing career satisfaction and appreciating nurse effort by positive communication cheering, support them, and reward for positive behaviour, all this give her a chance to exert her effort to achieve work goals.

The present study revealed that a negative correlation were found among staff nurses between loss of involvement with colleagues with ability for leading and overcoming challenges and good wage as motivating factors. Bad relationship with colleague leading them, 
distributing work and responsibilities will be hard with increasing objections and crushes in the work all this mean bad behaviour and increase of fault between staff and discount in wages and lose of rewards as a punishment(Kong et al. (2011).

In the same line a study done by De Bacquer et al. (2005) who found that the relationship between colleagues should be full of with cooperation and more skilful one should help less experience one to maintain that work goes smoothly, facilitate leading and will maintain positive behaviour and more success.

This study also revealed negative correlation were found among staff nurses between job dissatisfaction with promotion and growth, ability to benefit from opportunities and achieving goals, and being appreciated and respected. Promotion and growth, difficult chances to acquire more skills and to achieve progress, loss of support although of increasing workload increase disappointment and her dissatisfaction.

This agree with Dragano (2005)who reported that the lack of work motivators affects negatively in many sides of nurse work like deactivates her to achieve any progress in her work, feeling confuse about her role, loss of self-esteem and appreciation to her exerted effort and increase workload and responsibilities which increase work stress.

Concerning head nurses a negative correlationwere found between emotional stress and exhaustion with promotion and growth this may be due to that head nurses face many of emotional stress and exhaustion due to slow growing in position, dealing with lack of qualification with increase of critics, increase of workload and responsibilities and continuous dealing with challenges may increase head nurses feeling with dissatisfaction which increase burnout. This agree withBlau et al. (2003)who found that the continuous dealing with work responsibilities and needing to achieve success and depletes head nurse energy and increase their stress.

This study also shows that head nurses feeling of loss of appreciation was negatively correlation with their ability to benefits from opportunities and achieving goals and good wage as motivating factors. This agree with .Klonoski (2011) who reported that head nurse in leadership position and decreasing her appreciation or respect consider a failure in the work which decrease the ability to benefit from chance and opportunities that help her to achieve career success and growth. Moreover having a good wage is a part of evaluating their effort for leading, guiding, and directing the staff, not considered as a motivating factor for head nurses.

In the same line a study done by

Anwar and Elareed (2017)who found that loss of appreciation of the head nurse is a big mistake and should has the right for respect because head nurses in a position of leadership represent the management of organization and their effort in planning and managing the work need to be appreciated to motivate her to carry on and as a reward for experience and skills.

\section{Conclusion}

From the present study it was concluded that:

Head nurses were more career motivation than staff nurses, which considered themselves as being appreciated and respected, had high career promotion and growth, and had the abilities for leading and overcoming 
challenges. Nursing staff in hospitals not considered good wages as motivating factors. Staff nurses were more burnout than head nurses, suffering from job dissatisfaction and loss of appreciation.

Nearly, all study sample had moderate and high level of burnout. Although there was no relation between career motivation and nursing staff burnout, there was relation between most career motivation subscales and most burnout subscales.

\section{Recommendations}

Based on the findings of the study it's recommended to:

- Provide training program about burnout and how to avoid and overcome it.

- Encourage nursing staff to attain workshops, health conferences to enhance their career motivation.

- Create clear and joyful environment free from handicapped and especially in ICUs to enhance nursing staff to work and do their best.

- Establish good rewarding system not focused only on financial rewards especially in ICUs to attract and encourage nurses to work.

- Establish flexible policies schedules and routines to free nursing staff from work overload and give opportunities to growth and development in their career.

- Make nurses close to decision making and help them to share, and vote for decisions that will their future in the work.

- Establish good communication system between mangers and staff nurses to facilitate sharing of points of views.

- Establish a committee that discuss nursing staff problems and to make sure that solutions will applied as planned.

- Enhance working in groups and group cohesion to make sure that workload and responsibilities is distributed in equal and fair

References manner to prevent job stress.

Aiken, L. H. 2002. Hospital Nurse Staffing and Patient Mortality, Nurse Burnout, and Job Dissatisfaction. JAMA, 288: (16), 1987.

Ali, J., McInerney, D. M., Craven, R. G., Yeung, A. S. \& King, R. B. 2014. Socially Oriented Motivational Goals and Academic Achievement: Similarities Between Native and Anglo Americans. The Journal of Educational Research, 107: (2), 123-137.

Antoniou, A.-S., Ploumpi, A. \& Ntalla, M. 2013. Occupational stress and professional burnout in teachers of primary and secondary education: The role of coping strategies. Psychology, 4: (03), 349.

Anwar, M. M. \& Elareed, H. R. 2017. Burnout among Egyptian nurses. Journal of Public Health, 25: (6), 693-697.

Bagley, C., Abubaker, M. \& Sawyerr, A. 2018. Personality, work-life balance, hardiness, and vocation: A typology of nurses and nursing values in a special sample of English hospital nurses. Administrative Sciences, 8: (4), 79.

Banks, Z. M. \& Bailey, J. H. 2010. Career Motivation in Newly Licensed Registered Nurses: What Makes Them Remain. 15: (6), 1489-1503. 
Carr, P. L., Gareis, K. C. \& Barnett, R. C. 2003. Characteristics and Outcomes for Women Physicians Who Work Reduced Hours. Journal of Women's Health, 12: (4), 399-405.

Chin, W. W. 2010. How to write up and report PLS analyses. Handbook of partial least squares. Springer. 655-690.

De Bacquer, D., Pelfrene, E., Clays, E., Mak, R., Moreau, M., de Smet, P., et al. 2005. Perceived Job Stress and Incidence of Coronary Events: 3-Year Follow-up of the Belgian Job Stress Project Cohort. American Journal of Epidemiology, 161: (5), 434-441.

Dragano, N. 2005. Organisational downsizing and work stress: testing synergistic health effects in employed men and women. Journal of Epidemiology \& Community Health, 59: (8), 694699.

Hagbaghery, M. A., Salsali, M. \& Ahmadi, F. J. 2004. A qualitative study of Iranian nurses' understanding and experiences of professional power. 2: (1), 9.

Handbook, O. O. 2015. US Department of Labor, Bureau of Labor Statistics; 2014.

Kong, H., Cheung, C. \& Song, H. 2011. Hotel career management in China: Developing a measurement scale. International Journal of Hospitality Management, 30: (1), 112-118.

Le Blanc, EL-Shaer A, P., Risk A \& Schaufeli, W. B. 2008. Organizational structure features on occupational stress for intensive care nurses and strategies for dealing with stress.
Doctorate degree, faculty of nursing, Tanta University.

London, M. \& Sessa, V. I. 2006. Continuous learning in organizations: A living systems analysis of individual, group, and organization learning. Multi-level issues in social systems. Emerald Group Publishing Limited.

Long, C. S., Kowang, T. O., Ping, T. A. \& Muthuveloo, R. 2014. Investigation on the impact of job stressors on nurses in Malaysia. Asian Social Science, 10: (4), 67.

Maslach, C. \& Leiter, M. P. 2008. Early predictors of job burnout and engagement. Journal of Applied Psychology, 93: (3), 498.

Maslach, C. \& Leiter, M. P. 2016. Understanding the burnout experience: recent research and its implications for psychiatry. World psychiatry, 15: (2), 103-111.

Meyer, J. P. \& Maltin, E. R. 2010. Employee commitment and wellbeing: A critical review, theoretical framework and research agenda. Journal of Vocational Behavior, 77: (2), 323337.

Negarandeh, R., Oskouie, F., Ahmadi, F., Nikravesh, M. \& Hallberg, I. R. 2006. Patient advocacy: barriers and facilitators. $B M C$ Nursing, 5: (1).

Reyes, G. \& Conde, A. J. 2017. Career Commitment and Academic Motivation of Staff Nurses in the Philippines. 4: (1), 1073.

Riveros, A. M \& Tsai, T. S. 2011. Career commitment and organizational commitment in forprofit and non-profit sectors. International Journal of Emerging Sciences, 1: (3), 324-341. 
Seham Mohamed Abd El Rahman et. al.

Schaufeli, W., Leiter, M. \& Maslach, C. 2009. Burnout: 35 años de investigación and práctica. Career Dev. Int, 14: 204-220.

Smith, C. \& Worsfold, K. 2015. Unpacking the learning-work nexus:'priming'as lever for highquality learning outcomes in work-integrated learning curricula. Studies in Higher Education, 40: (1), 22-42.

Taylor, A. R. \& Hooley, T. 2014. Evaluating the impact of career

management skills module and internship programme within a university business school. British Journal of Guidance \& Counselling, 42: (5), 487-499.

Tzeng, H.-M. 2002. The influence of nurses' working motivation and job satisfaction on intention to quit: an empirical investigation in Taiwan. International Journal of Nursing Studies, 39: (8), 867-878. 